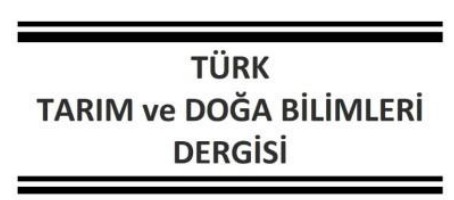

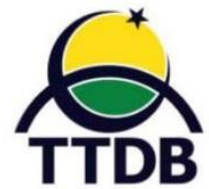

www.dergipark.gov.tr/turkjans

Araştırma Makalesi

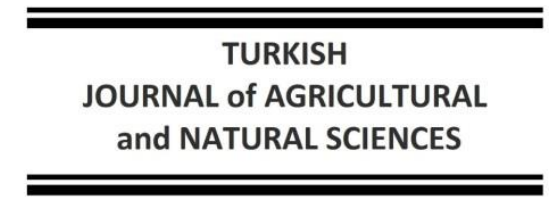

and NATURAL SCIENCES

\title{
Bor ve Çinko İçerikli Yaprak Gübresi Uygulamalarının Kiraz (Prunus avium L.) Meyvelerinin Bazı Kalite Özellikleri Üzerine Etkileri\&
}

\author{
Ali İKiNCi ${ }^{1 *}$, Şükran ALDANMAZ², İbrahim BOLAT ${ }^{1}$ \\ ${ }^{1}$ Harran Üniversitesi, Ziraat Fakültesi, Bahçe Bitkileri Bölümü, Şanlıurfa \\ ${ }^{2}$ Artuklu Tarım ve Orman illçe Müdürlüğü, Mardin \\ *Sorumlu Yazar: aliikinci@harran.edu.tr
}

Geliş Tarihi: 24.10.2020 Düzeltme Geliş Tarihi: 21.05.2021 Kabul Tarihi: 29.06.2021

\section{Öz}

Bu araştırma, Prunus mahaleb L. anacı üzerine aşılı 0900 Ziraat kiraz çeşidinde, bor ve çinko içerikli yaprak gübrelerinin bazı meyve kalite özellikleri üzerine etkilerini belirlemek amacıyla 2018 yılında Yeşilli (Mardin) ilçesindeki iki ayrı kiraz bahçesinde yürütülmüştür. Çalışmada; kontrol, 100 L suya 150 cc Maxifruit (1.

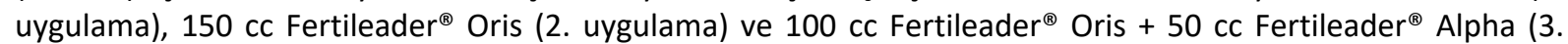
uygulama) yaprak gübreleri kullanılarak, tam çiçeklenmeden 15-30 gün ve tam çiçeklenmeden 30-45 gün sonra olmak üzere iki defa uygulama yapılmıştır. Araştırma kapsamında kullanılan yaprak gübrelerinin meyve çapı, meyve boyu, meyve eni, meyve sap uzunluğu, meyve eti sertliği ve SÇKM miktarı üzerine etkisinin önemli olduğu belirlenmiştir. 0900 Ziraat kiraz çeşidinde, bor ve çinko içerikli yaprak gübresi uygulamalarında en ağır meyveler $8.41 \mathrm{~g}$ ile 2. uygulamadan, en büyük meyve çapı $27.32 \mathrm{~mm}$ ile 2. uygulamadan, en uzun meyve sapı $50.52 \mathrm{~mm}$ ile 1. uygulamadan, meyve eti en sert olan meyveler $297.78 \mathrm{~g}$ ile 2 . uygulamadan, en yüksek $\mathrm{L}^{*}$ renk değeri 28.40 ile 2. uygulamadan, en yüksek a* renk değeri 14.35 ile 2. uygulamadan, en yüksek $b^{*}$ renk değeri 356.20 ile 2. uygulamadan, en düşük meyve suyu asitliği \%0.60 ile 1. uygulamadan ve en yüksek SÇKM oranı \%17.23 ile 2. uygulamadan elde edilmiştir.

Anahtar kelimeler: Yeşilli, Yaprak gübresi, Meyve ağırlığı, Meyve çapı, Meyve rengi, ŞÇKM

\section{Effects of Boron and Zinc Containing Foliar Fertilizer Applications on Some Quality Characteristics of Sweet Cherry (Prunus avium L.) Fruits}

\begin{abstract}
This research was carried out in two different cherry orchards in Yeşilli (Mardin) district in 2018 to determine the effects of boron and zinc-containing foliar fertilizers on some fruit quality traits in 0900 Ziraat cherry cultivar grafted on the rootstock of Prunus mahaleb L. In the study; control, using $150 \mathrm{cc}$ Maxifruit ( $1^{\text {st }}$ application), $150 \mathrm{cc}$ Fertileader ${ }^{\circledR}$ Oris ( $2^{\text {nd }}$ application) and $100 \mathrm{cc}$ Fertileader ${ }^{\circledR}$ Oris +50 cc Fertileader $^{\circledR}$ Alpha ( $3^{\text {rd }}$ application) leaf fertilizers in $100 \mathrm{~L}$ water, 15-30 days and 30-45 days after full bloom were applied twice. It was determined that the effect of leaf fertilizers used in the scope of the research on fruit diameter, fruit length, fruit width, fruit stem length, fruit flesh hardness and water soluble solid content was found to be significant. In 0900 Ziraat cherry cultivar, the heaviest fruits in foliar fertilizer applications with boron and zinc content are from the $2^{\text {nd }}$ application with $8.41 \mathrm{~g}$, the largest fruit diameter from the $2^{\text {nd }}$ application with 27.32 $\mathrm{mm}$, the longest fruit stem with $50.52 \mathrm{~mm}$ from the $1^{\text {st }}$ application, the hardest fruit flesh firmness $2^{\text {nd }}$ application with $297.78 \mathrm{~g}$, the highest $\mathrm{L}^{*}$ color value from the $2^{\text {nd }}$ application with 28.40 , the highest $\mathrm{a}^{*}$ color value from the $2^{\text {nd }}$ application with 14.35 , the highest $b^{*}$ color value from the $2^{\text {nd }}$ application with 356.20 , the lowest fruit juice acidity with $0.60 \%$ with the $1^{\text {st }}$ application and the highest soluble rate was obtained from the $2^{\text {nd }}$ application with $17.23 \%$.
\end{abstract}

Key words: Yeşilli, Foliar fertilizer, Fruit weight, Fruit diameter, Fruit color, Soluble solid content 


\section{Giriş}

Anavatanı Güney Kafkasya, Hazar Denizi ve Kuzeydoğu Anadolu olan kiraz (Prunus avium L.) (Özbek, 1978), ılıman iklim meyve türleri içerisinde meyvelerini en erken olgunlaştıran meyve türlerinden biri olup, üretim ve pazarlama açısından sıkça tercih edilmektedir (Öz, 1988; Balta ve Yarılgaç, 1996). Kirazın köken merkezlerinden biri durumunda bulunan ülkemiz, dünyada geniş bir yetiştirilme alanına sahip olup, bu meyvenin üretiminde ön sıralarda yer almaktadır (Anonim, 2000). Dünya toplam kiraz üretim miktarı 2547 946 tondur (FAOSTAT, 2018). Türkiye 639564 ton kiraz üretim miktarı ile birinci sırada yer alırken, ülkemizi sırasıyla ABD (312 430 ton), Özbekistan (172 035 ton), Şili (155 935 ton), İran (137 268 ton), İtalya (114 798 ton) ve İspanya (106 584 ton) takip etmektedir (FAOSTAT, 2018). Ülkemiz, 2018 yılı FAO kayıtlarına göre Şili (184 566 ton), Hong Kong (138 312 ton) ve ABD (83 972 ton)'nin ardından 75 304 ton kiraz ihracatı ile dördüncü sırada yer almaktadır.

Kiraz dış satımında söz sahibi ülkeler arasına girerek yüksek düzeyde gelir elde etmek, ülkemizin kalkınması açısından büyük önem arz etmektedir (Sütyemez, 2000). Dış ticaret için önemli olan, özellikle erken ve geç mevsimde pazara sunma açısından ekolojimizde yetişen kirazlar, Avrupa ülkelerinde yetiştirilenlere göre daha avantajlı durumdadır.

Meyve ağaçlarında verim ve kaliteyi etkileyen nedenler içerisinde, bitkilerin beslenmesi ile ilgili sorunlar önemli bir yer tutar. Bu sorunların ortaya çıkarılması ve giderilmesi için yaprak ve toprak analizleri sonuçlarına göre bitki besleme uygulamaları yapılmalıdır (Uysal ve Katkat, 2005). Bitki besin maddeleri noksanlıklarının belirlenmesi ve giderilmesi ile ilgili çalışmalar, özellikle son yıllarda değişik yörelerdeki farklı meyve türlerinde mikro elementler üzerinde yoğunlaşmıştır (Ülgen ve ark., 1971, Gedikoğlu 1990). Eyüpoğlu ve ark. (1998), ülkemiz topraklarında en yaygın olduğu düşünülen iz elementi eksikliklerinin sırası ile çinko ve demir olduğunu bildirmişlerdir. Aynı araştırıcılar yaptıkları çalışmada, Türkiye topraklarında görülen çinko eksikliğinin pH'sı 8'den fazla, organik madde içeriği \%1'in altında ve killi-tın bünyede topraklarda daha fazla görüldügünü saptamışlardır.

Kiraz yetiştiriciliğinde meyve verim ve kalitesini etkileyen en önemli etkenlerden birisi de topraklardaki mikro element noksanlığıdır. Pek çok meyve türünde olduğu gibi kiraz ağaçlarının beslenmesinde, mikro elementlerden olan çinko ve bor oldukça önemlidir. Bor elementi karbonhidrat metabolizmasının düzenlenmesi, fenolik bileşiklerin, aminoasitlerin ve proteinlerin sentezinde rol alması nedeniyle, bitki gelişimi için zorunlu elementlerdendir. Yeteri kadar bor elementi alamayan meyve ağaçlarında çiçek tomurcuğu oluşumu, polen üretimi, polen tüpü gelişimi, optimum tozlanma ve yeterli meyve tutumu gelişimi sağlanamaz (Balcı ve Çağlar, 2006; Wöjcik ve Wojcik, 2006; Kocabaş, 2009; Gerçekçioğlu ve ark., 2019). Kirazda yeterli düzeyde meyve tutumu için bor anahtar bir rol oynamaktadır.

Öte yandan çinko elementi ise enzim aktivitesinde oynadığı rol nedeniyle protein, karbonhidrat ve oksin metabolizmalarında çok önemli bir elementtir (Yağmur ve ark., 2002; Çakıcı ve Arslan, 2012). Eksikliğinde meyve sayısında düşüş göze çarpar. Pek çok kez meyve iriliğinde de küçülmeler gözlenmiştir. Çinko eksikliğinde indol asetik asitin yeteri kadar oluşmaması nedeniyle büyüme ve gelişmede sorunlar ortaya çıkar. Çoğunlukla toprak pH'sının yüksek olması ( $\mathrm{pH}^{\prime} \mathrm{sı}$ 8 'den fazla) ve toprak bünyesinden kaynaklanan bu sorunun, yapraktan gübrelemeler ile giderilmesi hem çabuk hem de daha ekonomik olabilmektedir.

Ülkemizdeki kiraz bahçelerinde ve kiraz ağaçları üzerinde yürütülen bazı çalışmalarda yaygın şekilde bor, çinko ve demir eksikliklerinin bulunduğu ve ağaçların bu noksanlıklardan büyük ölçüde etkilendiği tespit edilmiştir. Köseoğlu (1995), Uluborlu ve Senirkent yörelerinde yaptığı çalışmasında, kiraz bahçelerinin demir ve mangan besin elementleri açısından yetersiz, bakır ve çinko elementleri açısından yeterli olduğunu belirlemiştir. Gökoğlan (2017), Kahramanmaraş ilinde 0900 Ziraat kiraz ağaçları üzerinde geç sonbaharda yapraktan bor (B) uygulanması sonucunda; (iki yıllık verilere göre) meyve ağırlığında (\%10.71), meyve boyunda (\%5.20), meyve eninde (\%6.33), çekirdek ağırlığında (\%26.67), sap uzunluğunda (\%9.73), meyve eti sertliğinde (\%3.40), meyve suyu pH'sında (\%10.20), meyvenin C vitamin kapsamında (\%81.95) artışlar olduğunu tespit etmiştir.

Bu çalışmada; kireç içeriği yüksek, organik madde oranı düşük ve bitki besin elementleri bakımından fakir toprak koşullarına sahip Mardin ili Yeşilli ilçesindeki 0900 Ziraat ağaçları üzerine uygulanan bor ve çinko içerikli yaprak gübrelerinin, meyvelerin bazı kalite özellikleri üzerine etkileri araştırılmıştır.

\section{Materyal ve Metot}

Bu çalışma, 2018 yılı yetiştiricilik sezonunda Mardin ili Yeşilli ilçesinde belirlenen 2 ayrı üreticiye ait idris (Prunus mahaleb L.) anacı üzerine aşılı, tam verime yatmış ve $7 \times 6 \mathrm{~m}$ dikim mesafesinde kurulu 0900 Ziraat kiraz çeşidi bahçelerinde yürütülmüştür. Bahçelerde, 0900 Ziraat çeşidine tozlayıcı çeşit olarak Stark Gold çeşidi kullanılmıştır. 
Deneme bahçelerinde gerekli kültürel işlemler, standartlara uygun şekilde yapılmıştır. Deneme, tesadüf blokları deneme desenine göre 3 tekerrürlü ve her tekerrürde 3 ağaç olacak şekilde planlanmıştır.

Çalışma kapsamında Timac Agro firmasına ait değişik içerikli yaprak gübreleri kullanılmıştır. Kiraz ağaçlarının çiçeklenme ve meyve tutumunun teşviki, meyve iriliği ve sayısında artış, sağlam ve eşit büyüklükte meyve eldesi için Maxifruit (N: \% 3, P: \% 7, K: \% 1, Mn: \% 0.05, Zn: \% 0.10), B kaynağı olarak Fertileader ${ }^{\circledR}$ Alpha (N: \% 6.5, P: \% 12.6, B: \% 4.2) ve Zn kaynağı olarak Fertileader ${ }^{\circledast}$ Oris (N: \% 3,
P: \% 15.0, Zn: \% 4.8) isimli ticari yaprak gübreleri kullanılmıştır. Çalışmada, kiraz ağaçlarına uygulanan ticari yaprak gübrelerinin uygulama zamanı ve uygulama konsantrasyonları Çizelge 1'de verilmiştir. Uygulamalar 2018 yılı bahar döneminde tam çiçeklenmeden 15-30 gün (25 Nisan 2018) ve tam çiçeklenmeden 30-45 gün (18 Mayıs 2018) sonra yapılmıştır. Kontrol grubu ağaçlara ise sadece yayıcı-yapıştırıcı ilave edilmiş saf su püskürtülmüştür.

Çizelge 1. Yaprak gübrelerinin uygulama aralığı ve uygulama şekli

\begin{tabular}{|c|c|c|}
\hline Uygulamalar & $\begin{array}{c}\text { Tam çiçeklenmeden } \\
15-30 \text { gün sonra }\end{array}$ & $\begin{array}{c}\text { Tam çiçeklenmeden } \\
30-45 \text { gün sonra }\end{array}$ \\
\hline Kontrol & Saf su püskürtüldü & Saf su püskürtüldü \\
\hline 1. Uygulama & Maxifruit (150 cc/100 L su) & Maxifruit (150 cc/100 L su) \\
\hline 2. Uygulama & Fertileader ${ }^{\oplus}$ Oris (150 cc/100 L su) & Fertileader ${ }^{\circledR}$ Oris $(150 \mathrm{cc} / 100 \mathrm{~L} \mathrm{su})$ \\
\hline 3. Uygulama & $\begin{array}{l}\text { Fertileader }{ }^{\circledR} \text { Oris (100 cc/100 L su) } \\
+ \\
\text { Fertileader }{ }^{\circledR} \text { Alpha }(50 \mathrm{cc} / 100 \mathrm{~L} \mathrm{su})\end{array}$ & $\begin{array}{c}\text { Fertileader }{ }^{\circledR} \text { Oris }(100 \mathrm{cc} / 100 \mathrm{~L} \mathrm{su}) \\
+ \\
\text { Fertileader }{ }^{\circledR} \text { Alpha }(50 \mathrm{cc} / 100 \mathrm{~L} \mathrm{su})\end{array}$ \\
\hline
\end{tabular}

\section{Meyve kalite özellikleri}

Uygulama ağaçlarından optimum derim zamanında her tekerrür için rastgele toplanan 25 adet meyvede yapılan pomolojik analizler ile saptanmıştır. Hasat edilen kiraz meyvelerinde meyve ağırlığı (g), meyve çapı $(\mathrm{mm})$, meyve eni $(\mathrm{mm})$, meyve boyu $(\mathrm{mm})$, meyve sap uzunluğu $(\mathrm{mm})$, çekirdek ağırlığı (g), meyve eti sertliği (g kuvvet), suda çözülebilir kuru madde miktarı (\%), $\mathrm{pH}$ ve titre edilebilir asitlik (\%) değerleri tespit edilmiştir (Koyuncu ve ark., 1999; Bolsu ve Akça, 2011; Gerçekçioğlu ve ark., 2019). Meyve ağırlığı, meyve örneklerinin 0.001 g'a duyarlı dijital teraziyle (NJW-300, Universal Weight Enterprise Co., Ltd., Taiwan) tartılmasıyla gram (g) olarak belirlenmiştir. Meyve örneklerinin $0.01 \mathrm{~mm}$ 'ye duyarlı dijital kumpas (Mitutoyo, Japonya) yardımıyla meyve çapı $(\mathrm{mm})$, meyve boyu $(\mathrm{mm})$, meyve eni $(\mathrm{mm})$ ve sap uzunluğu ölçümü yapılmıştır. Çekirdek ağırlığı; deneme ağaçlarından toplanan kiraz meyvelerinin çekirdekleri çıkarılarak, $0.001 \mathrm{~g}$ duyarlılıktaki dijital terazide tartım ile belirlenmiştir. Meyve eti sertliği, her uygulama için rastgele seçilen 10 adet meyvenin her iki yanak kısmından el penetrometresi (Effegi, FT 011) ile 1.75 mm'lik silindirik uç kullanılarak ölçülmüş, elde edilen değerlerin ortalaması alınmıştır. Sonuçlar gkuvvet olarak ifade edilmiştir. Meyve kabuk rengi, meyvelerin ekvator bölgesindeki 2 farklı noktasından Konica Minolta CM-3220D marka masa tipi spektrofotometre ile ölçülmüştür.
Okunan renk değerleri $L^{*}, a^{*}, b^{*}$ olarak ifade edilmiştir. Suda Çözünür Kuru Madde Miktarı (SÇKM); meyve örneklerinin suyu çıkarılarak, suda çözünür kuru madde miktarı "Greinorm" marka el refraktometresiyle (Greinorm, Almanya)) oda sıcaklığında $\left(20^{\circ} \mathrm{C}\right)$ ölçülmüştür. Sonuçlar \% olarak ifade edilmiştir (Karaçalı, 2014). Titre edilebilir asit miktarı, $5 \mathrm{ml}$ meyve suyunun $0.1 \mathrm{~N} \mathrm{NaOH}$ ile $\mathrm{pH}$ 8.1'e kadar titre edilmesi ile harcanan $\mathrm{NaOH}$ miktarından hesaplanmış ve $\mathrm{g}$ malik asit/100 ml olarak ifade edilmiştir (Karaçalı, 2014). pH değeri, meyve örneklerinden çıkartılan meyve sularının $\mathrm{pH}$ değeri, masaüstü $\mathrm{pH}$ ölçer (Thermo Scientific Orion, ABD) yardımıyla ölçülmüştür.

\section{İstatistiksel analizler}

Deneme sonunda elde edilen veriler tesadüf blokları deneme deseni esas alınarak, TARIST istatistik paket programı kullanılarak varyans analizine tabi tutulmuştur. Ortalamalar arasındaki farklılıklar LSD testi ile belirlenmiştir (Açıkgöz ve ark. 1993).

\section{Bulgular ve Tartışma}

Araştırmanın yürütüldüğü bahçe topraklarının fiziksel ve kimyasal analiz sonuçları Çizelge 2'de verilmiştir. Çizelge 2'de yer alan toprak örneklerine ait sonuçlardan da görüleceği gibi, deneme alanlarının killi-tın bünyeli, organik madde içeriklerinin çok düşük, tuzluluk sorununun olmadığı, pH değerinin 8.05 ve bazik karakterli 
özellik gösterdiği belirlenmiştir. Toprağın elverişli besin elementlerinden $\mathrm{Ca}, \mathrm{Mg}$ ve $\mathrm{Fe}$ içeriklerinin fazla, $\mathrm{K}$ ve $\mathrm{Cu}$ konsantrasyonlarının yeterli; $\mathrm{P}, \mathrm{Zn}$ ve B konsantrasyonlarının noksan, $\mathrm{Mn}$ konsantrasyonunun ise yetersiz olduğu anlaşılmıştır (Lindsay ve Norvell, 1978; FAO, 1990; TOVEP, 1991; Eyüpoğlu ve ark., 1999).

Çizelge 2. Araştırmanın yürütüldüğü bahçe topraklarının fiziksel ve kimyasal özellikleri

\begin{tabular}{|c|c|c|c|c|c|c|c|c|}
\hline Bahçeler & Tuz & $\begin{array}{l}\mathrm{pH} \\
(\%)\end{array}$ & $\begin{array}{c}\text { Kireç } \\
(\%)\end{array}$ & $\begin{array}{c}\text { Organik } \\
\text { Madde } \\
(\%)\end{array}$ & $\begin{array}{c}P \\
(\mathrm{ppm})\end{array}$ & $\begin{array}{c}\mathrm{K} \\
(\mathrm{ppm})\end{array}$ & $\begin{array}{c}\text { Ca } \\
\text { (ppm) }\end{array}$ & $\begin{array}{c}\mathrm{Mg} \\
(\mathrm{ppm})\end{array}$ \\
\hline I. Bahçe & 0.02 & 8.05 & 15.02 & 0.81 & 3.90 & 229.5 & 5602 & 740.16 \\
\hline \multirow[t]{2}{*}{ II. Bahçe } & 0.02 & 8.05 & 18.23 & 1.31 & 5.53 & 293.5 & 5560 & 791.85 \\
\hline & $\begin{array}{c}\mathrm{Fe} \\
(\mathrm{ppm})\end{array}$ & & $\begin{array}{c}\mathrm{Cu} \\
(\mathrm{ppm})\end{array}$ & \multicolumn{2}{|c|}{$\begin{array}{c}\mathrm{Zn} \\
(\mathrm{ppm})\end{array}$} & $\underset{(p p m)}{M n}$ & \multicolumn{2}{|r|}{$\begin{array}{c}\text { B } \\
(\mathrm{ppm})\end{array}$} \\
\hline I. Bahçe & 9.59 & & 2.81 & \multicolumn{2}{|c|}{0.35} & 12.99 & \multicolumn{2}{|r|}{0.61} \\
\hline II. Bahçe & 11.58 & & 3.61 & \multicolumn{2}{|c|}{0.50} & 18.71 & \multicolumn{2}{|r|}{0.18} \\
\hline
\end{tabular}

\section{Meyve ağırlığı, meyve çapı, meyve boyu ve meyve yüksekliği}

Çalışmada, iki ayrı lokasyonda bulunan 0900 Ziraat kiraz çeşidi ağaçlarına uygulanan bor (Fertileader ${ }^{\circledR}$ Alpha) ve çinko (Fertileader ${ }^{\circledR}$ Oris) içerikli yaprak gübrelerinin ortalama meyve ağırlığına etkisi önemsiz bulunmuştur (Çizelge 3). Her iki bahçedeki uygulama sonuçlarına göre en yüksek ortalama meyve ağırlığı $8.41 \mathrm{~g}$ ile 2 . uygulama'dan, en düşük ortalama meyve ağırlığı değeri ise $8.23 \mathrm{~g}$ ile kontrol ağaçlarındaki meyvelerden elde edilmiştir (Şekil 1). Tokat ili merkez ilçesi Kocacık köyünde Prunus mahaleb L. anacı üzerine aşılı '0900 Ziraat' kiraz çeşidi ağaçlarına çiçeklenme sonunda $0.4 \mathrm{ppm}$ bor uygulamasında $11.30 \mathrm{~g}$ ortalama meyve ağırlığı değeri elde edilmiştir (Gerçekcioğlu ve ark., 2019). Iğdır koşullarında Gisela 5 anacı üzerine aşılı 0900 Ziraat kiraz çeşidi ağaçlarına tam çiçeklenme zamanında farklı kimyasalların uygulandığı bir çalışmada, ortalama 9.13-10.72 g (Sevilmiş, 2018) arasında ortalama meyve ağırlığı değerleri elde edilirken, İzmir ili Kemalpaşa ilçesi koşullarında, Prunus mahaleb L. anacı üzerine aşılı 0900 Ziraat çeşidinin ortalama meyve ağırlığı $9.56 \mathrm{~g}$ (Eroğul, 2016), Şanlıurfa koşullarında SL 64 klonal idris (Prunus mahaleb L.) anacı üzerine aşılı '0900 Ziraat' kiraz çeşidinin ortalama meyve ağırlığı $8.88 \mathrm{~g}$ (ikinci ve Bolat, 2015), Çanakkale ili Lapseki ilçesi koşullarında kuş kirazı anacına aşılı 0900 Ziraat çeşidinin ortalama meyve ağırlığı $6.80-8.10 \mathrm{~g}$ arasında (Delice ve ark., 2012), Tokat koşullarında idris (Prunus mahaleb L.) anacı üzerine aşılı olan 0900 Ziraat çeşidinin ortalama meyve ağırlığı $6.56 \mathrm{~g}$ (Bolsu ve Akça, 2011), Isparta ili Uluborlu ilçesi koşullarında kuş kirazı anacı üzerine aşılı '0900 Ziraat' kiraz çeşidi meyvelerinin ortalama meyve ağırlığı 7.95-10.02 g (Yıldırım ve Koyuncu, 2010) arasında ve Yalova ekolojik koşullarında yürütülen bir araştırmada, SL 64 anacı üzerine aşılı 0900 Ziraat çeşidinin ortalama meyve ağırlığı $9.70 \mathrm{~g}$ (Burak ve ark., 2008) olarak saptanmıştır. Araştırmamızda elde etmiş olduğumuz meyve iriliği sonuçlarının, yurdumuzun değişik bölgelerinde yapılan çalışmalarla benzerlik gösterdiği belirlenmiştir.

Yaprak gübreleri uygulamalarının 0900 Ziraat kiraz çeşidinin meyvelerinde meyve çapına etkisi $(p<0.05)$ önemli olmuştur (Çizelge 3). Uygulamaların ortalamalarına göre en yüksek meyve çapı değeri $27.32 \mathrm{~mm}$ ile 2. uygulama yapılan ağaçların meyvelerinde saptanırken, en düşük meyve çapı değerleri ise $25.06 \mathrm{~mm}$ ile kontrol ve $25.07 \mathrm{~mm}$ ile 3. uygulama yapılan ağaçların meyvelerinden elde edilmiştir (Çizelge 3 ve Şekil 1). Gerçekcioğlu ve ark. (2019), Tokat ili koşullarında 0900 Ziraat kiraz çeşidi meyvelerinin ortalama meyve çapını 28.85 mm; Eroğul (2016), İzmir ili Kemalpaşa ilçesi koşullarında 27.39 mm; İkinci ve Bolat (2015), Şanlıurfa ili koşullarında 21.56 mm; Delice ve ark. (2012), Çanakkale ili koşullarında 20.7-26.3 mm arasında; Bolsu ve Akça (2011), Tokat ili Turhal ilçesi koşullarında 21.96 $\mathrm{mm}$; Yıldırım ve Koyuncu (2010) ise Isparta ili Uluborlu ilçesi koşullarında 24.69 - 25.30 mm arasında saptamışlardır.

Meyve boyu üzerine bor ve çinko içerikli yaprak gübrelerinin etkisinin önemli olduğu saptanmıştır (Çizelge 3). En yüksek ortalama meyve boyu $25.70 \mathrm{~mm}$ ile 2 . uygulamadan, en düşük meyve boyu değeri ise $23.07 \mathrm{~mm}$ ile kontrol ağaçlarının meyvelerinden elde edilmiştir. İkinci ve Bolat (2015), Şanlıurfa ili koşullarında yetiştirilen 0900 Ziraat kiraz çeşidi meyvelerinin ortalama meyve boyunu $19.91 \mathrm{~mm}$; Delice ve ark. (2012), Çanakkale ili Lapseki ilçesi koşullarında 19.4-24.8 
mm arasında; Bolsu ve Akça (2011), Tokat ili Turhal ilçesi koşullarında 20.68 mm; Yıldırım ve Koyuncu (2010) ise Isparta ili Uluborlu ilçesi koşullarında $23.60-25.32 \mathrm{~mm}$ arasında saptamışlardır. Meyve eni üzerine bor ve çinko içerikli yaprak gübrelerinin etkisi $(p<0.05)$ önemli olmuştur (Çizelge 3 ). Uygulama ortalamalarına göre en yüksek meyve eni $21.77 \mathrm{~mm}$ ile 2. uygulama ve $21.62 \mathrm{~mm}$ ile 1. uygulama ağaçlarının meyvelerinde, en düşük meyve eni ise $19.45 \mathrm{~mm}$ ile kontrol ve $19.93 \mathrm{~mm}$ ile 3. uygulama'da belirlenmiştir. Íkinci ve Bolat (2015), Şanlıurfa ili koşullarında yetiştirilen 0900 Ziraat kiraz çeşidi meyvelerinin ortalama meyve enini 19.84 mm; Bolsu ve Akça (2011) ise Tokat ili Turhal ilçesi koşullarında $19.01 \mathrm{~mm}$ olarak saptamışlardır. Bulgularımız hem kontrol ağaçlarındaki hem de diğer yapılan çalışmaları sonuçları ile karşılaştıııldığında meyvelerde meyve boyu ve meyve enini önemli ölçüde artırmıştır.

\section{Meyve sap uzunluğu, çekirdek ağırlığı ve meyve eti sertliği}

Çalışmada uygulanan bor ve çinko içerikli yaprak gübrelerinin 0900 Ziraat kiraz çeşidinin meyvelerinde meyve sap uzunluğu, çekirdek ağırlığı ve meyve eti sertliğine etkisi Çizelge 4'te sunulmuştur. Meyve sap uzunluğu üzerine bor ve çinko içerikli yaprak gübrelerinin etkisinin $(p<0.01)$ önemli olduğu saptanmıştır (Çizelge 4). Uygulamalar arasındaki ortalamalara göre en yüksek meyve sap uzunluğu $50.52 \mathrm{~mm}$ ile 1 . uygulamadaki meyvelereden, en düşük meyve sap uzunluğu ise $45.94 \mathrm{~mm}$ ile 2 . uygulamaya ait meyvelerden elde edilmiştir. Gerçekcioğlu ve ark. (2019), 0900 Ziraat kiraz çeşidi meyvelerinin ortalama sap uzunluğunu 48.34 - $51.16 \mathrm{~mm}$ arasında; ikinci ve Bolat (2015), 50.13 mm; Bolsu ve Akça (2011), 45.89 mm; Yıldırım ve Koyuncu (2010) ise 47.04 - $49.48 \mathrm{~mm}$ olarak tespit etmişlerdir. Meyve çekirdek ağırlığı üzerine bor ve çinko içerikli yaprak gübrelerinin etkisi önemsiz olmuştur (Çizelge 4). 0900 Ziraat çeşidinde bakır ve çinko içerikli yaprak gübresi uygulamalarında, en yüksek çekirdek ağırlığı 0.57 g ile 3 . uygulama'da, en düşük çekirdek ağırlığı $0.53 \mathrm{~g}$ ile kontrol ağaçlarının meyvelerinde tespit edilmiştir. Gerçekcioğlu ve ark. (2019), 0900 Ziraat kiraz çeşidi meyvelerinin çekirdek ağırlığını 0.42 - $0.47 \mathrm{~g}$ arasında; Eroğul (2016), 0.38 g; İkinci ve Bolat (2015), 0.54 g; Bolsu ve Akça (2011), 0.60 g; Yıldırım ve Koyuncu (2010) ise $0.31-0.36 \mathrm{~g}$ arasında tespit etmişlerdir.

Meyve eti sertliği üzerine bor ve çinko içerikli yaprak gübrelerinin etkisi $(p<0.05)$ önemli bulunmuştur (Çizelge 4). Her iki bahçede uygulanan yaprak gübreleri ortalamasına göre en yüksek meyve eti sertliği 297.78 g ile 2. uygulamaya ait meyvelerden, en düşük meyve eti sertliği ise 278.87 g kontrola ait ağaçların meyvelerden elde edilmiştir. Gerçekcioğlu ve ark. (2019), Tokat ili koşullarında 0900 Ziraat kiraz çeşidi meyvelerinin ortalama meyve eti sertliğini $0.48-0.80 \mathrm{~N}$ (Newton) arasında, Eroğul (2016), İzmir ili Kemalpaşa ilçesi koşullarında $9.56 \mathrm{~N}$; Delice ve ark. (2012), Çanakkale ili Lapseki ilçesi koşullarında 1058 g; Pehlivan ve ark. (2012), Iğdır ili Kuzugüden köyü ekolojik koşullarında 273 g; Yıldırım ve Koyuncu (2010) ise Isparta ili Uluborlu ilçesi koşullarında 7.45 - $9.63 \mathrm{~N}$ arasında tespit etmişlerdir.

\section{Meyve kabuk rengi}

Çalışmada uygulanan bor ve çinko içerikli yaprak gübrelerinin 0900 Ziraat kiraz çeşidinin meyve parlaklık $\left(L^{*}\right)$ değeri üzerine etkisi önemsiz bulunmuştur (Çizelge 5). Uygulama ortalamalarına göre meyvelerde en yüksek $L^{*}$ değeri 28.40 ile 3 . uygulamasına ait meyvelerden, en düşük $L^{*}$ değeri ise 27.58 ile kontrol ağaçlarına ait meyvelerden elde edilmiştir.

Kiraz meyvelerine kırmızı rengi veren a* değeri üzerine etkisi önemsiz bulunmuştur (Çizelge 5). Meyvelerde en düşük a* renk değeri 11.89 ile kontroldeki ağaçların meyvelerinden, en yüksek $a^{*}$ renk değeri ise 14.35 ile 2 . uygulamaya ait ağaçların meyvelerinden elde edilmiştir.

Kiraz meyvelerine sarı rengi veren $b^{*}$ renk değeri üzerine yaprak gübrelerinin etkisi önemsiz bulunmuştur (Çizelge 5). Meyvelerde uygulama ortalamalarına göre en düşük $b^{*}$ renk değeri 2.40 ile kontrol ağaçlarına ait meyvelerden, en yüksek $b^{*}$ renk değeri 3.56 ile 2 . uygulamaya ait ağaçların meyvelerinden elde edilmiştir.

Faniadis ve ark. (2010), Yunanistan koşullarında farklı yükseltilerde yetiştirilen ve değişik depolama koşullarında muhafaza etmiş oldukları Burlat, Van, Tragana ve Mpakirtzeika kiraz çeşitlerine ait meyveler üzerinde yürütmüş oldukları çalışmalarında, Burlat kiraz çeşidinin en kırmızı renkli çeşit olduğunu $\left(a^{*}=28.7\right)$, bu çeşidi Van $\left(a^{*}=24.1\right)$ ve diğer çeşitlerin (ortalama $a^{*}=$ 19.7) izlediği belirlemişlerdir. Yürütülen bu araştırmada, kiraz çeşitlerinin $L^{*}$ değerlerini 27.7 32.1, a* değerlerinin 11.8 - 30.4 ve $b^{*}$ renk değerlerinin de -8.27 - (-) 0.59 arasında olduğu saptanmıştır. Yıldırım ve Koyuncu (2010) ise 0900 Ziraat çeşidi meyvelerinin $L^{*}$ değerlerini 21.79 30.00 , a* değerlerini 16.36 - 24.36 ve $b^{*}$ renk değerlerini ise 3.65 - 7.76 arasında tespit etmişlerdir. 
Çizelge 3. Mardin ili Yeşilli ilçesinde 0900 Ziraat kiraz çeşidinde bor ve çinko içerikli yaprak gübresi uygulamalarının ortalama meyve ağırlığı, meyve eni, meyve boyu ve meyve yüksekliğine etkisi

\begin{tabular}{|c|c|c|c|c|c|c|c|c|c|c|c|c|}
\hline \multirow[b]{2}{*}{ Uygulamalar } & \multicolumn{3}{|c|}{ Meyve ağırlığı (g) } & \multicolumn{3}{|c|}{ Meyve çapı (mm) } & \multicolumn{3}{|c|}{ Meyve boyu (mm) } & \multicolumn{3}{|c|}{ Meyve eni (mm) } \\
\hline & 1. Bahçe & $\begin{array}{l}2 . \\
\text { Bahçe }\end{array}$ & Ort. & 1. Bahçe & 2. Bahçe & Ort. & $\begin{array}{l}1 . \\
\text { Bahçe }\end{array}$ & 2. Bahçe & Ort. & 1. Bahçe & 2. Bahçe & Ort. \\
\hline Kontrol & $8.42 a b$ & $8.03 b$ & $8.23^{\text {öd }}$ & $25.21^{\text {öd }}$ & $24.90 \mathrm{~b}$ & $25.06 \mathrm{~b}$ & $22.57^{\circ \ddot{d}}$ & $23.58 \mathrm{~b}$ & $23.07^{\text {öd }}$ & $19.30 \mathrm{~b}$ & $19.60 \mathrm{bc}$ & $19.45 b$ \\
\hline 1. Uygulama & $8.62 a$ & $7.95 b$ & 8.29 & 25.71 & $27.00 \mathrm{~b}$ & $26.36 \mathrm{ab}$ & 22.61 & $25.02 b$ & 23.82 & $21.62 a$ & $21.62 \mathrm{ab}$ & $21.62 a b$ \\
\hline 2. Uygulama & $8.36 a b$ & $8.46 a b$ & 8.41 & 25.10 & $29.54 a$ & $27.32 a$ & 23.52 & $28.88 a$ & 25.70 & $19.34 b$ & $24.20 a$ & $21.77 a$ \\
\hline 3. Uygulama & $7.93 c$ & $8.62 \mathrm{a}$ & 8.28 & 24.63 & $25.51 b$ & $25.07 \mathrm{~b}$ & 22.81 & $23.87 \mathrm{~b}$ & 23.34 & $20.54 \mathrm{ab}$ & $19.32 \mathrm{c}$ & $19.93 \mathrm{~b}$ \\
\hline $\begin{array}{l}\text { Bahçe } \\
\text { Ortalaması }\end{array}$ & $8.33^{\text {öd }}$ & 8.27 & & 25.17B & $26.74 A$ & & 22.88B & $25.09 \mathrm{~A}$ & & $20.20^{\circ \mathrm{dd}}$ & 21.18 & \\
\hline $\begin{array}{l}\text { Varyans } \\
\text { Değeri }\end{array}$ & \multicolumn{3}{|c|}{$\begin{array}{l}\text { LSD Uygulama: Ö.D; } \\
\text { LSD }_{\text {Bahçe: Ö.D }}\end{array}$} & \multicolumn{3}{|c|}{$\begin{array}{l}\text { LSD Uygulama: } 1.487 * ; \\
\text { LSD }_{\text {Bahçe: }} 1.052^{* *}\end{array}$} & \multicolumn{3}{|c|}{$\begin{array}{l}\text { LSD Uygulama: } 1.325^{* *} \text {; } \\
\text { LSD }_{\text {Bahçe: }} 0.937^{* *}\end{array}$} & \multicolumn{3}{|c|}{ 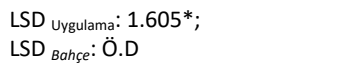 } \\
\hline
\end{tabular}

*: P< 0.05, **:P<0.01; Ö.D.: Önemli Değil

Aynı sütunda ve satırda farklı harflerle gösterilen ortalamalar arasındaki farklılık istatistiki olarak önemlidir.

Çizelge 4. Hasat edilen meyve örneklerinde meyve sap uzunluğu, çekirdek ağırlığı ve meyve eti sertliği istatistiki sonuçları

\begin{tabular}{|c|c|c|c|c|c|c|c|c|c|}
\hline \multirow[b]{2}{*}{ Uygulamalar } & \multicolumn{3}{|c|}{ Meyve Sap Uzunluğu (mm) } & \multicolumn{3}{|c|}{ Çekirdek ağırlığı (g) } & \multicolumn{3}{|c|}{ Meyve eti sertliği (g) } \\
\hline & 1. Bahçe & 2. Bahçe & Ort. & 1. Bahçe & 2. Bahçe & Ort. & 1. Bahçe & 2. Bahçe & Ort. \\
\hline Kontrol & $49.81^{\text {öd }}$ & $46.67 a b$ & $48.24 a b$ & $0.48 \mathrm{~b}$ & $0.58 \mathrm{ab}$ & $0.53^{\text {öd }}$ & $284.44 \mathrm{~b}$ & $273.30 \mathrm{~b}$ & $278.87 \mathrm{~b}$ \\
\hline 1. Uygulama & 47.92 & $53.12 \mathrm{a}$ & $50.52 \mathrm{a}$ & $0.55 \mathrm{a}$ & $0.54 \mathrm{~b}$ & 0.54 & $285.00 \mathrm{~b}$ & 293.33 a & 289.17 a \\
\hline 2. Uygulama & 46.77 & $45.10 \mathrm{~b}$ & $45.94 \mathrm{~b}$ & $0.54 \mathrm{a}$ & $0.54 a b$ & 0.54 & $305.55 \mathrm{a}$ & $290.00 \mathrm{a}$ & 297.78 a \\
\hline \multirow{2}{*}{$\begin{array}{l}\text { 3. Uygulama } \\
\text { Bahçe } \\
\text { Ortalaması }\end{array}$} & 46.35 & $45.68 \mathrm{~b}$ & $46.02 \mathrm{~b}$ & $0.55 a$ & $0.59 \mathrm{a}$ & 0.57 & $282.22 \mathrm{~b}$ & $292.78 \mathrm{a}$ & $287.50 \mathrm{ab}$ \\
\hline & $47.71^{\text {öd }}$ & 47.64 & & $0.53 \mathrm{~A}$ & $0.56 \mathrm{~B}$ & & $289.31^{\text {od }}$ & 287.35 & \\
\hline \multirow{2}{*}{ Varyans Değeri } & \multicolumn{3}{|c|}{ LSD Uygulama: $2.549 * *$} & \multicolumn{3}{|c|}{ LSD Uygulama: Ö.D } & \multirow{2}{*}{\multicolumn{3}{|c|}{ LSD Uygulama: $10.279 *$}} \\
\hline & \multicolumn{3}{|c|}{ LSD Bahçe: Ö.D } & \multicolumn{3}{|c|}{ LSD Bahçe: $0.023^{* *}$} & & & \\
\hline
\end{tabular}

*: $\mathrm{P}<0.05, * *: \mathrm{P}<0.01$; Ö.D.: Önemli Değil

Aynı sütunda ve satırda farklı harflerle gösterilen ortalamalar arasındaki farklılık istatistiki olarak önemlidir.

\section{Asitlik, pH ve SÇKM değerleri}

Çalışmada uygulanan bor ve çinko içerikli yaprak gübrelerinin 0900 Ziraat kiraz çeşidinin asitlik, pH ve suda çözünür kuru madde miktarına (SÇKM) etkisi Çizelge 6'da verilmiştir. Bor ve çinko içerikli yaprak gübresi uygulamalarının 0900 Ziraat kiraz çeşidi meyvelerinin titre edilebilir asit miktarına etkisi önemsiz bulunmuştur. Her iki bahçede yapılan uygulamaların ortalama sonuçlarına göre, en yüksek titre edilebilir asit miktarı \%0.65 ile kontrole ait ağaçlardaki meyvelerde, en düşük titre edilebilir asit miktarı ise $\% 0.60$ ile 1 . uygulamaya ait ağaçların meyvelerinden elde edilmiştir (Çizelge 6 ve Şekil 2). Yurdumuzun bazı önemli kiraz yetiştiricilik yörelerinde yapılan çalışmalarda, Gerçekcioğlu ve ark. (2019), Tokat ili koşullarında 0900 Ziraat kiraz çeşidinin titre edilebilir asitlik miktarını \% 0.60 0.63 arasında; Eroğul (2016), İzmir ili Kemalpaşa ilçesi koşullarında \% 0.83; İkinci ve Bolat (2015), Şanlıurfa ili koşullarında \% 0.54; Delice ve ark. (2012), Çanakkale ili Lapseki ilçesi koşullarında \% 0.62; Bolsu ve Akça (2011), Tokat ili Turhal ilçesi koşullarında \% 1.14; Yıldırım ve Koyuncu (2010) ise Isparta ili Uluborlu ilçesi koşullarında \% 0.58 - 0.64 arasında tespit etmişlerdir.

İki farklı bahçede yer alan 0900 Ziraat kiraz çeşidi ağaçlarına uygulanan yaprak gübrelerinin, meyvenin $\mathrm{pH}$ miktarına etkisinin önemsiz olduğu saptanmıştır (Çizelge 6). Uygulamalar arasındaki en yüksek meyve $\mathrm{pH}$ miktarı 4.26 ile kontrol ve 3 . uygulamaya ait ağaçların meyvelerinde, en düşük pH miktarı ise 4.05 ile 1 . uygulamaya ait ağaçların meyvelerinden elde edilmiştir. Tokat ekolojik koşullarında yürütülen bir araştırmada 0900 Ziraat kiraz çeşidinin meyve suyu $\mathrm{pH}$ değeri 4.12-4.18 (Gerçekcioğlu ve ark., 2019) arasında, İzmir ili Kemalpaşa ilçesi koşullarında 3.76 (Eroğul, 2016), Şanlıurfa ili koşullarında 3.59 (ikinci ve Bolat, 2015), Tokat ili Turhal ilçesi koşullarında 4.21 (Bolsu ve Akça, 2011) ve Isparta ili Uluborlu ilçesi koşullarında ise 3.85-3.92 (Yıldırım ve Koyuncu, 2010) arasında saptanmıştır.

Kirazlara uygulanan bor ve çinko içerikli yaprak gübrelerinin meyvelerin suda çözünebilir kuru madde miktarına (SÇKM) etkisi $(p<0.01)$ önemli olmuştur (Çizelge 6). Her iki bahçede yapılan gübre uygulamaların ortalamalarına göre, en yüksek SÇKM miktarı \% 17.23 ile 2. uygulamaya ait ağaçların meyvelerinden, en düşük SÇKM miktarı ise \% 16.60 ile kontrol ve \% 16.70 ile 3. uygulamaya ait ağaçların meyvelerinden elde edilmiştir (Şekil 2). Yurdumuzun değişik yörelerinde yapılan bazı çalışmalarda Gerçekcioğlu ve ark. (2019), Tokat ili koşullarında 0900 Ziraat kiraz çeşidinin SÇKM miktarını \%16.04 - 17.50 arasında; Eroğul (2016), İzmir ili Kemalpaşa ilçesi koşullarında \%13.66; İkinci ve Bolat (2015), Şanlıurfa ili 
koşullarında \% 18.48; Delice ve ark. (2012), Çanakkale ili Lapseki ilçesi koşullarında \%14.0; Bolsu ve Akça (2011), Tokat ili Turhal ilçesi koşullarında \%16.08; Yıldırım ve Koyuncu (2010) ise
Isparta ili Uluborlu ilçesi koşullarında \%16.10 16.48 arasında tespit etmişlerdir.

Çizelge 5. Hasat edilen meyvelerde meyve kabuk rengi istatistiki sonuçları

\begin{tabular}{|c|c|c|c|c|c|c|c|c|c|}
\hline \multirow{2}{*}{ Uygulamalar } & \multicolumn{3}{|c|}{$\begin{array}{c}\text { Meyve kabuk rengi } \mathrm{L}^{*} \\
\text { değeri }\end{array}$} & \multicolumn{3}{|c|}{$\begin{array}{c}\text { Meyve kabuk rengi } a^{*} \\
\text { değeri }\end{array}$} & \multicolumn{3}{|c|}{$\begin{array}{c}\text { Meyve kabuk rengi b* } \\
\text { değeri }\end{array}$} \\
\hline & 1. Bahçe & 2. Bahçe & Ort. & 1. Bahçe & 2. Bahçe & Ort. & 1. Bahçe & 2. Bahçe & Ort. \\
\hline Kontrol & $27.41^{\text {öd }}$ & $27.75^{\text {öd }}$ & $27.58^{o ̈ d}$ & $11.86^{\text {öd }}$ & $11.92^{o ̈ d}$ & $11.89^{o ̈ d}$ & $2.57^{\text {öd }}$ & $2.23^{\text {öd }}$ & $2.40^{\text {öd }}$ \\
\hline 1. Uygulama & 26.81 & 28.48 & 27.64 & 10.04 & 17.34 & 13.69 & 1.97 & 4.43 & 3.20 \\
\hline 2. Uygulama & 28.02 & 27.95 & 27.98 & 15.36 & 13.35 & 14.35 & 4.16 & 2.96 & 3.56 \\
\hline 3. Uygulama & 28.32 & 28.50 & 28.40 & 14.06 & 14.49 & 14.27 & 3.41 & 2.90 & 3.16 \\
\hline $\begin{array}{l}\text { Bahçe } \\
\text { Ortalaması }\end{array}$ & $27.64^{\ddot{d} d}$ & 28.17 & & $12.82^{\text {öd }}$ & 14.28 & & $3.03^{o ̈ d}$ & 3.13 & \\
\hline $\begin{array}{l}\text { Varyans } \\
\text { Değeri }\end{array}$ & $\begin{array}{l}\text { LSD Uygulan } \\
\text { LSD }_{\text {Bahçe }}:\end{array}$ & $\begin{array}{l}\text { ma: Ö.D; } \\
\text { Ö.D }\end{array}$ & & $\begin{array}{l}\text { LSD Uygulan } \\
\text { LSD }_{\text {Bahçe }}:\end{array}$ & $\begin{array}{l}\text { ma: Ö.D; } \\
\text { Ö.D }\end{array}$ & & $\begin{array}{l}\text { LSD Uygulam } \\
\text { LSD }_{\text {Bahçe: }}: \dot{C}\end{array}$ & $\begin{array}{l}\text { na: Ö.D; } \\
\text { Oे.D }\end{array}$ & \\
\hline
\end{tabular}

*: $\mathrm{P}<0.05,{ }^{* *}: \mathrm{P}<0.01 ;$ Ö.D.: Önemli Değil

Aynı sütunda ve satırda farklı harflerle gösterilen ortalamalar arasındaki farklılık istatistiki olarak önemlidir.

Çizelge 6. 0900 Ziraat çeşidine bor ve çinko içerikli yaprak gübresi uygulamasının meyvelerin bazı kimyasal özellikleri üzerine etkisi

\begin{tabular}{|c|c|c|c|c|c|c|c|c|c|}
\hline \multirow{2}{*}{ Uygulamalar } & \multicolumn{3}{|c|}{ Asitlik (\%) } & \multicolumn{3}{|c|}{$\mathrm{pH}$} & \multicolumn{3}{|c|}{ SÇKM (\%) } \\
\hline & 1. Bahçe & 2. Bahçe & Ort. & 1. Bahçe & 2. Bahçe & Ort. & 1. Bahçe & 2. Bahçe & Ort. \\
\hline Kontrol & $0.58^{\text {öd }}$ & $0.71^{\text {öd }}$ & $0.65^{\text {öd }}$ & $4.50^{\circ o ̈ d}$ & $3.97^{\circ ̈ d}$ & $4.26^{\text {öd }}$ & $17.00 \mathrm{~b}$ & $16.20 \mathrm{c}$ & $16.60 \mathrm{~b}$ \\
\hline 1. Uyg. & 0.54 & 0.66 & 0.60 & 4.07 & 4.03 & 4.05 & $17.00 \mathrm{~b}$ & $17.40 \mathrm{a}$ & $17.20 \mathrm{a}$ \\
\hline 2. Uyg. & 0.54 & 0.69 & 0.61 & 4.50 & 4.03 & 4.25 & $18.15 \mathrm{a}$ & $16.50 \mathrm{~b}$ & $17.23 a$ \\
\hline 3. Uyg. & 0.54 & 0.75 & 0.64 & 4.50 & 4.02 & 4.26 & $17.00 \mathrm{~b}$ & $16.40 \mathrm{bc}$ & $16.70 \mathrm{~b}$ \\
\hline $\begin{array}{l}\text { Bahçe } \\
\text { Ortalaması }\end{array}$ & 0.55 B & $0.70 \mathrm{~A}$ & & $4.39 \mathrm{~A}$ & $4.00 \mathrm{~B}$ & & $17.29 \mathrm{~A}$ & $16.63 \mathrm{~B}$ & \\
\hline Varyans & LSD Uygula & : Ö.D & & LSD Uygulan & na: Ö.D & & LSD Uygulam & : 0.194** & \\
\hline Değeri & LSD Bahçe: & $0.045^{* *}$ & & LSD Bahçe: & $0.352^{*}$ & & LSD Bahçe: & $.137^{* *}$ & \\
\hline
\end{tabular}

*: P< 0.05, **:P<0.01; Ö.D.: Önemli Değil

Aynı sütunda ve satırda farklı harflerle gösterilen ortalamalar arasındaki farklılık istatistiki olarak önemli 

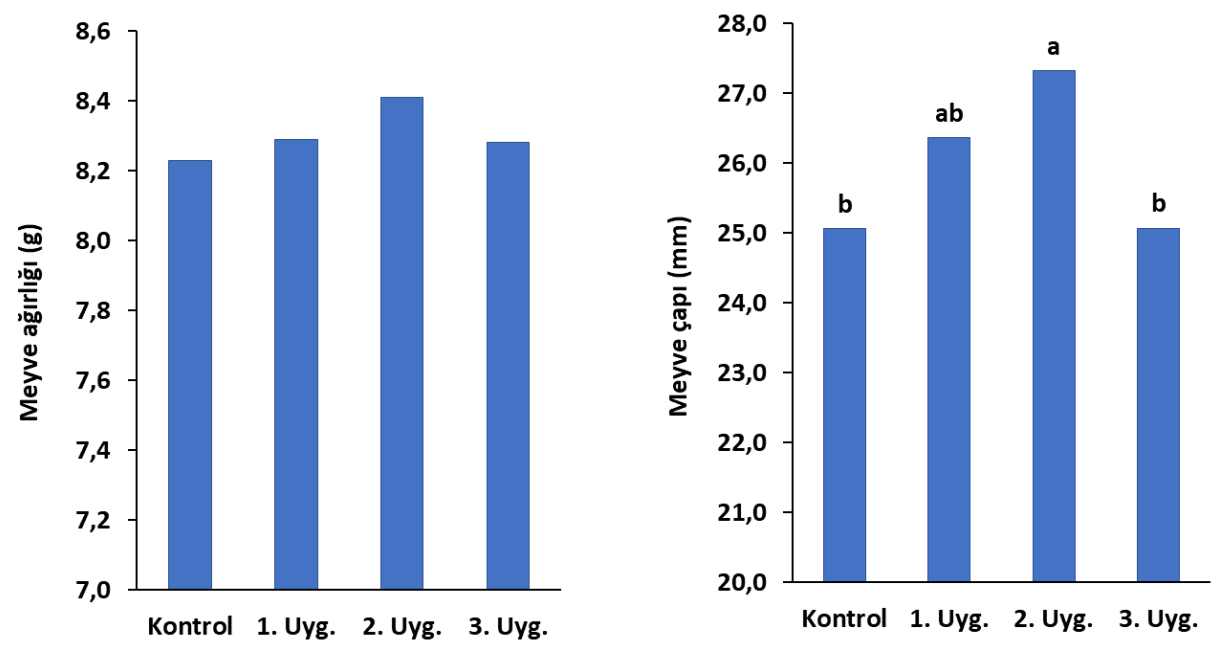

Şekil 1. Bor ve çinko içerikli yaprak gübresi uygulamalarının 0900 Ziraat kiraz çeşidinin ortalama meyve ağırlığı ve meyve çapına etkisi
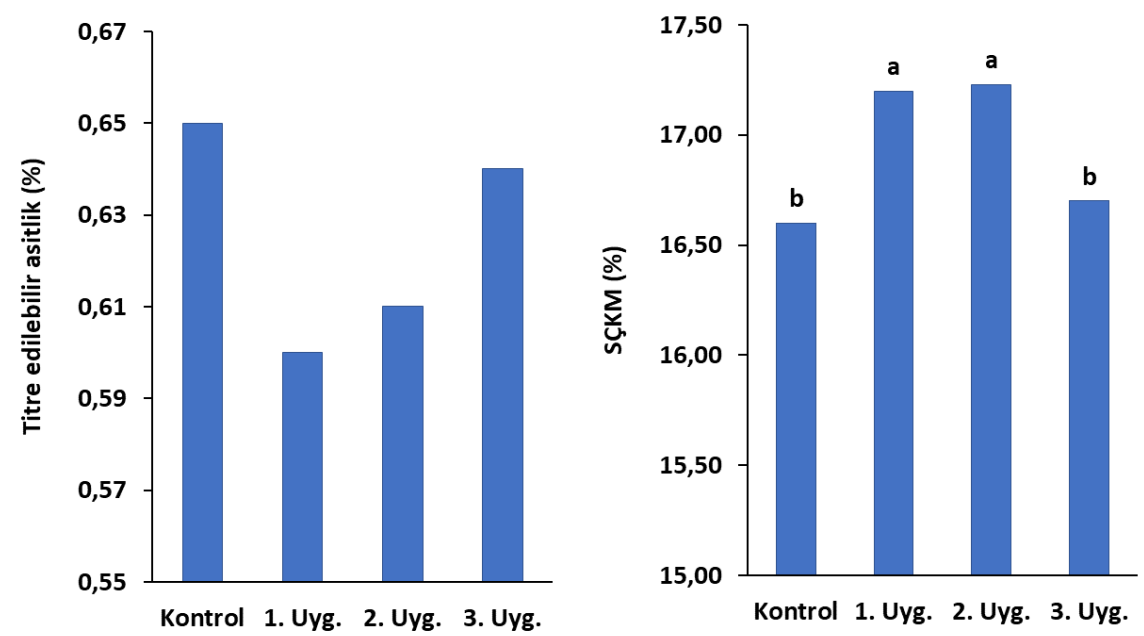

Şekil 2. Yaprak gübresi uygulamalarının 0900 Ziraat kiraz meyvelerinin titre edilebilir asitlik ve SÇKM oranları üzerine etkisi

\section{Sonuç ve Öneriler}

Bu çalışma, Güneydoğu Anadolu Bölgesi'nde yer alan ve önemli miktarda kiraz üretimi yapılan Mardin iline bağlı Ömerli ilçesinde meyve kalitesinin iyileştirilmesi ve verimin arttırılması bakımından yapılan ilk çalışmalardan biri olması açısından önemlidir. Su yetersizliği, toprakta düşük organik madde kapsamı, topraklarının yüksek kireç içeriği ve buna bağı olarak toprak pH'sının yüksekliği bitkilerin besin elementi ihtiyaçlarının karşılanması için yapraktan gübre uygulamasını zorunlu kılmaktadır. Yörede, kiraz üreticilerinin yaprak ve toprak analizi sonuçlarına göre uygun gübreleme programı kullanarak, kaliteli, ihracata uygun, taşımaya ve depolamaya dayanıklı kiraz meyvesi elde etmeleri, yöre halkı için gelir getirici kiraz bahçelerine olan talebi artıracaktır.

Yeşilli ilçesindeki 0900 Ziraat kiraz çeşidi yetiştiriciliği yapılan iki ayrı bahçedeki ağaçlara püskürtülen değişik içerikteki yaprak gübrelerinin, kiraz satışında en çok aranan kalite kriterlerinden olan meyve ağırlığı ve meyve çapı üzerine önemli etkisi olmuştur. Bunların yanında, yaprak gübresi uygulamalarının meyve eti sertliği, meyve rengi ve SÇKM miktarını arttırdığı, buna karşılık meyve suyunun titre edilebilir asit miktarını önemli düzeyde olmasa da düşürdüğü belirlenmiştir. Kiraz meyvesinin bazı kalite kriterleri üzerine, araştırmada kullanmış olduğumuz bor ve çinko içerikli yaprak gübrelerinin etkilerindeki farklı sonuçların ortaya çıkmasındaki nedenin, uygulamaların yapıldığı yetiştiricilik döneminde, tüm ülke genelinde bahar aylarında uzun yıllar yöre ortalamasının neredeyse 2 katı yağan yağmurdan kaynaklandığı düşünülmektedir. Mardin ilindeki kiraz yetiştiriciliğinin daha da geliştirilmesi için, gelecekte gerek topraktan gerekse yapraktan 
gübre uygulamalarıyla ilgili çalışmalara ağırlık verilmesi yararlı olacaktır.

\&: Bu çalışma; Harran Üniversitesi, Fen Bilimleri Enstitüsü tarafından kabul edilen ikinci yazara ait "Kiraz (Prunus avium L.) Meyvelerinin Bazı Kalite Özellikleri Üzerine Bor ve Çinko İçerikli Yaprak Gübresi Uygulamalarının Etkileri" isimli Yüksek Lisans Tez çalışmasının bir bölümünden üretilmiştir.

Teşekkür: $\mathrm{Bu}$ araştırma, Harran Üniversitesi Bilimsel Araştırma Projeleri (BAP) Koordinatörlüğü tarafından 18139 nolu proje kapsamında desteklenmiştir. Harran Üniversitesi Bilimsel Araştırma Projeleri Koordinatörlüğü'ne destekleri için teşekkür ederiz.

Çıkar Çatışması Beyanı: Makale yazarları aralarında herhangi bir çıkar çatışması olmadığını beyan ederler.

Araştırmacıların Katkı Oranı Beyan Özeti: Yazarlar makaleye eşit oranda katkı sağlamış olduklarını beyan ederler.

\section{Kaynaklar}

Açıkgöz, N., Aktaş, M.E., Maughaddam, A. ve Özcan, K. 1993. TARIST. PC'ler için İstatistik ve Kantitatif Genetik Paketi. Uluslararası Bilgisayar Uygulamaları Sempozyomu-133, 19 Ekim 1993, Konya, s:10-19.

Anonim. 2000. Kiraz Raporu. DPT Beş Yıllık Kalkınma Planı Bitkisel Ürünler (Meyve Grubu) Özel İhtisas Komisyonu, Ankara, s:126-149.

Balcı, S. ve Çağlar, S. 2006. Meyve yetiştiriciliğinde bor uygulaması. Birinci Uluslararası Bor Sempozyumu. 3-4 Ekim 2002, Kütahya. Bildiriler Kitabı, s:189-192.

Balta, F.ve Yarılgaç, T. 1996. Van ekolojisinde yetiştirilen Bing, Lambert ve Van kiraz çeşitleri üzerinde fenolojik ve pomolojik incelemeler. YYÜ Tar. Bil. Dergisi, 6(1): 4350.

Bolsu, A, ve Akça, Y. 2011. Mahlep anacı üzerine aşılı 5 kiraz çeşidinin bazı morfolojik özellikleri ile meyve kalite özelliklerinin belirlenmesi. Yüzüncü Yıl Üniversitesi Tarım Bilimleri Dergisi, 21(3): 152-157.

Burak, M., Akçay, M., Yalçınkaya, E. ve Türkeli, Y. 2008. Effect of some clonal rootstocks on growth and earliness of '0900 Ziraat' sweet cherry, Acta Hortic. 795; 199-202.

Çakıcı, H. ve Arslan, H. 2012. Yapraktan potasyum, bor ve çinko uygulamalarının Camarosa çilek çeşidinde verim ve kaliteye etkisi. Ege Üniv. Ziraat Fak. Derg., 49(3): 293-298.

Delice, A., Ekinci, N., Özdüven, F. F. ve Gür, E. 2012. Lapseki'de yetiştirilen 0900 Ziraat kiraz çeşidinin kalite özellikleri ve ekolojik faktörler. Tekirdağ Ziraat Fakültesi Dergisi, 9(3): 27-34.

Eroğul, D. 2016. İzmir ilinde yetiştirilen bazı önemli kiraz çeşitlerinin fiziksel ve kimyasal özelliklerinin belirlenmesi. YYÜ Tar. Bil. Dergisi, 26(4): 579-585.

Eyüpoğlu, F., Kurucu, N. ve Talaz, S. 1999. Türkiye topraklarının bitkiye yarayışlı bazı mikro elementler ( $\mathrm{Fe}, \mathrm{Cu}, \mathrm{Zn}, \mathrm{Mn}$ ) bakımından genel durumu. T.C. Başbakanlık Köy Hizmetleri Genel Müdürlüğü, Toprak ve Gübre Araştırma Enstitüsü Müdürlüğü, 72s. Ankara.

Faniadis, D., Drogoudi, P.D. ve Vasilakakis, M. 2010. Effects of cultivar, orchard elevation, and storage on fruit quality characters of sweet cherry (Prunus avium L.). Scientia Horticulturae, 125(3): 301-304.

FAO. 1990. Micronutrient assesment at the country level: an international study. FAO Soils Bulletin 63, Rome.

FAOSTAT. 2018. Food and Agriculture Organization of The United Nations (FAO). http://www.fao.org/faostat/en/\#data/QC (Erişim tarihi: 07.09.2020).

Gedikoğlu, i. 1990. Ankara yöresinde armut ağaçlarında görülen mikro besin maddeleri noksanlıklarının teşhisi ve tedavisi. Toprak ve Gübre Araştırma Enstitüsü Yayınları, Genel Yayın No: 163, Rapor Serisi No: 85, Ankara.

Gerçekçioğlu, R., Asarkaya, U. ve Atasever, Ö.Ö. 2019. '0900 Ziraat' kiraz çeşidinde bor uygulamasının verim ve meyve kalitesine etkisi. Gaziosmanpaşa Bilimsel Araştırma Dergisi (GBAD), 8(3): 120-129.

Gökoğlan, B. 2017. Yapraktan bor uygulamasının 0900 Ziraat kiraz çeşidinin meyve tutumuna etkisi. Kahramanmaraş Sütçü İmam Üniversitesi, Fen Bilimleri Enstitüsü, Bahçe Bitkileri Anabilim Dalı, Yüksek Lisans Tezi, Kahramanmaraş, 38s.

İkinci. A. ve Bolat, I, 2015. Bazı kiraz çeşitlerinin GAP bölgesindeki performanslarının incelenmesi. Harran Tarım ve Gıda Bilimleri Dergisi, 19 (2): 54-65.

Kocabaş, I. 2009. Elma yetiştiriciliğinde bor uygulamasının önemi. TABAD Tarım Bilimleri Araştırma Dergisi, 2(1): 127-130.

Koyuncu, M.A,, Koyuncu, F. ve Kazankaya, A. 1999. Van ekolojik koşullarında yetiştirilen bazı kiraz çeşitlerinin optimum derim 
zamanlarının saptanması üzerine bir araştırma. Türkiye III. Ulusal Bahçe Bitkileri Kongresi, 14-17 Eylül, Ankara. s: 690-694.

Köseoğlu, A.T. 1995. Uluborlu ve Senirkent yörelerinde yetiştirilen kirazların beslenme durumlarının belirlenmesi. II. Mikro Besin Elementleri, Turkish Journal of Agriculture and Forestry, 19: 349-353.

Lindsay, W. L. ve Norwel, W. 1978. Development of a DTPA soil test for zinc, Iron, manganase and copper. Soil Science of America, 42: 421-428.

Öz, F. 1988. Kiraz ve Vişne. Tarımsal Araştırmaları Destekleme ve Geliştirme Vakfı Yayın No: 16, Yalova.

Özbek, S. 1978. Özel Meyvecilik. Kışın Yaprağını Döken Meyve Türleri. Ç.Ü. Ziraat Fakültesi Yayınları No: 128. Ders Kitabı, 483s, Adana.

Sevilmiş, E. 2018. Kirazda bazı kimyasal uygulamaların meyve kalitesi üzerine etkileri. Iğdır Üniversitesi Fen Bilimleri Enstitüsü, Yüksek Lisans Tezi, Iğdır, 38s.

Sütyemez, M. 2000. Bazı kiraz çeşitlerinde GA3 uygulamalarının meyve tutum ve meyve kalitesi üzerine etkileri. Kahramanmaraş Sütçü İmam Üniversitesi, Fen ve Mühendislik Dergisi, 3(1): 43-48.

TOVEP. 1991. Türkiye toprakları verimlilik envanteri. T.C. Tarım Orman ve Köy İşleri Bakanlığı, Köy Hizmetleri Genel Müdürlüğü.
Uysal, E. ve Katkat, A.V. 2005. Bursa ve çevresinde yetiştirilen kiraz ağaçlarının demir, çinko, mangan ve bakır ile beslenme durumları. Uludağ Üniversitesi Ziraat Fakültesi Dergisi, 19(2): 47-59.

Ülgen, N., Uygun, Ş., Aksu, S., Işık, H. ve Selimoğlu, F. 1971. Meyve ağaçlarında iz element araştırmaları. Toprak ve Gübre Araştırma Enstitüsü 1969-1971 Araştırma Raporu. s: 86-90, Ankara.

Wöjcik, P. ve Wojcik, M. 2006. Effect of boron fertilization on sweet cherry tree yield and fruit quality. Journal of Plant Nutrition, 29(10): 1755-1766.

Yağmur, B., Ceylan, Ş. ve Oktay, M. 2002. Çinko gübrelemesinin çekirdeksiz üzümde (Vitis vinifera cv. Sultani Çekirdeksiz) verime etkisi, Ege Üniversitesi Ziraat Fakültesi Dergisi, 39(2), 111-117.

Yıldırım, A.N. ve Koyuncu, F. 2010. The effect of gibberellic acid applications on the cracking rate and fruit quality in the '0900 Ziraat' sweet cherry cultivar. African Journal of Biotechnology, 9(38): 6307-6311. 